International Journal of Instruction e-ISSN: 1308-1470 • www.e-iji.net

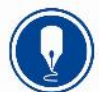

January $2022 \bullet$ Vol.15, No.1

p-ISSN: 1694-609X

pp. 381-400

Article submission code:

20201218135813
Received: 18/12/2020

Revision: 01/07/2021
Accepted: 25/07/2021

OnlineFirst: 24/10/2021

\title{
A Meta-Analysis of the Last Two Decades of Realistic Mathematics Education Approaches
}

Dadang Juandi

Assoc. Prof., Universitas Pendidikan Indonesia, dadang.juandi@upi.edu

Yaya Sukjaya Kusumah

Prof., Universitas Pendidikan Indonesia,yayaskusumah@yahoo.com

\section{Maximus Tamur}

Asst. Prof., Universitas Katolik Indonesia Santu Paulus Ruteng, maximustamur@unikastpaulus.ac.id

Today, hundreds of studies on the technique known as Realistic Mathematics Education (RME) have been discovered. Numerous trials yielding contradicting results. The purpose of this meta-analysis is to ascertain the overall effect of RME and to examine the moderator variables in order to explore the consequences. The ERIC database, Sage publications, Springer publications, semantic scholars, and Google scholars were used to identify empirical data. The study examined 54 effect sizes from 38 individual studies conducted in the past two decades, involving 6140 participants. The estimation procedure was according to the random effects model, and statistical calculations were performed using the CMA program. According to the research findings, the study's overall effect size was 0.97. This suggests that implementing RME has a significant favourable influence on pupils' mathematical abilities. Moderator variables analysis shows that RME implementation would be more efficient when considering sample size, intervention length, learning mix, and education level. This finding contributes to the future implementation of RME to consider those variables that are shown to moderate the studies' effect sizes. Finally, comparisons of RME across countries and limitations of the study are discussed, providing vital information as a starting point for later studies and development of RME.

Keywords: realistic mathematics education, mathematical ability, meta-analysis, moderator variables, effect size

\section{INTRODUCTION}

Mathematical ability is ability to complete mathematical tasks and effectively solve given mathematical problems (Karsenty, 2014). Students' mathematical abilities can be formed using relevant learning approaches (Marzuki, Wahyudin, Cahya, \& Juandi, 2021; Nurjanah, Latif, Yuliardi, \& Tamur, 2020). Same with that Güler (2018)

Citation: Juandi, D., Kusumah, Y. S., \& Tamur, M. (2022). A meta-analysis of the last two decades of realistic mathematics education approaches. International Journal of Instruction, 15(1), 381-400. https://doi.org/10.29333/iji.2022.15122a 
highlighted the importance of students to connect with mathematics courses in real life. Meanwhile, the use of context as a starting point for learning can promote students' academic abilities and make mathematics more enjoyable (Laurens, Batlolona, Batlolona, \& Leasa, 2018; Özdemir, 2017; Sawatzki, 2015).

Learning that makes this real situation the starting point of learning is a feature of the Realistic Mathematics Education (RME) approach. RME is a unique teaching theory for the mathematical domain (Van den Heuvel-Panhuizen \& Drijvers, 2014). This approach's peculiarity is that it gives rich and "realistic" situations a prominent position in learning activities. This situation acts as an entry point to explore students' initial knowledge and gradually becomes more formal (Van den Heuvel-Panhuizen \& Drijvers, 2020). RME today inspired international curriculum and colored mathematics learning (Prahmana, Sagita, Hidayat, \& Utami, 2020). RME helps teachers to improve students' math skills (Hasibuan, Saragih, \& Amry, 2019; Tanujaya, Prahmana, \& Mumu, 2017). This is because RME equips students with the tools necessary to think critically, discuss, and solve real-world problems. This recommendation generated a research frenzy on RME.

The RME method is known to influence mathematical abilities of students. However, previous studies into this theoretical assumption produced mixed results. Research conducted by Ardiyani (2018), Hirza \& Kusumah (2014), Palinussa (2013), Saleh et al. (2018), Son, Darhim, \& Fatimah (2020) demonstrates the efficacy of the RME strategy. Meanwhile, some research results do not support these findings (Yuniati, Armiati, \& Musdi, 2020; Yuanita, Zulnaidi, \& Zakaria, 2018). Multiple investigations within a single study frequently produce inconsistent, and as a result, forming conclusions concerning research issues can be subjective (Franzen, 2020; Juandi \& Tamur, 2021). Educators want precise information that can be considered when implementing RME. In other words, systematic study is required to comprehend the relationship between mathematical talents and the moderator's role in RME application.

Quantitative studies must be included to close this gap and give useful data for policymakers (Higgins \& Katsipataki, 2015). As a result, a meta-analysis research is required to synthesize and evaluate the findings of individual investigations, as well as to analyze the causes of result variance for consideration in their future application. Meta-analysis provides in-depth and accurate conclusions (Fadhli, Brick, Setyosari, Ulfa, \& Kuswandi, 2020; Siddaway, Wood, \& Hedges, 2019). Thus when definitive conclusions are desired, the results of numerous individual studies must be taken into account using meta-analysis methods (Franzen, 2020).

Previously, Chen, Shih, \& Law (2020), Clark, Tanner-Smith, \& Killingsworth (2016), and Wouters \& Van Oostendorp (2013) conducted a meta-analysis study on the effects of gamification approach related to RME. The study's findings showed that introducing kids to learning through games had a little impact on their mathematical achievement. Game-based learning is one of the characteristics of RME, but it does not mean that RME is equated with that method. As a result, the research findings do not adequately explain the effect of RME. 
In previous study, we studied the effect of RME over the last ten years and found that applying RME has a reasonably strong positive effect on the mathematical abilities of students (Tamur, Juandi, \& Adem, 2020). However, this study only includes individual studies on RME in Indonesia. In line with that, analysis of studies from abroad and within the geographical region is needed to conduct a more up-to-date meta-analysis study (Çiftçi \& Yıldız, 2019; Demirel \& Dağyar, 2016). Additionally, the majority of these studies focus exclusively on unpublished research outputs, such as master's theses, thesis, and doctorate dissertations. Meanwhile, conducting the meta-analysis using only unpublished publications, such as theses, master's theses, and theses introduces publication bias (Borenstein, Hedges, Higgins, \& Rothstein, 2009).

Recent research has categorized the RME research trend, namely, reviewing 110 articles collected from a database of ten accredited national journals in Indonesia over the past two decades. The researchers identified seven categories, including the predominance of published RME articles, RME research themes, mathematics topics, student skills, RME terminology, and research methodologies utilized (Prahmana, Sagita, Hidayat, \& Utami, 2020). A study on RME in the last two decades has been conducted by Zulkardi, Putri, \& Wijaya (2020). In their review, the researchers explained how RME came to Indonesia, the decision of the Indonesian government to send six doctoral candidates to the Netherlands, the results of the RME development to the development of the PMRI Center of Excellence, and the establishment of a doctoral program in the PMRI field (Zulkardi, Putri, \& Wijaya, 2020). Both studies did not use quantitative methods and statistical tests. In line with that, Prahmana, Sagita, Hidayat, \& Utami (2020) suggest the need for further studies that are more quantitatively oriented to arrive at more general results.

This study expands previous studies by evaluating RME's overall impact on mathematical abilities of students. Investigations into the causes of effect size variation between individual studies were carried out by analyzing the relationship between identified moderator variables, namely, "difference in sample size," "difference in educational level," "duration of experimental intervention," "combination of learning," and "RME implementation countries." The results of this study provide educators with reliable information on future RME implementation. These ideas and the following questions drive this research. Does RME implementation produce larger effect sizes than conventional mathematical approaches? Do differences in sample size, level of education, experimental duration, learning combination, and geographical region of implementation of RME affect the study's overall effect size?

\section{METHOD}

This study employs meta-analysis to comb through a large number of papers in national and international journals. The study concerned the impact of applying RME to the mathematical domain. Generally, Borenstein et al. (2009) summarize the steps of metaanalysis, beginning with the establishment of inclusion criteria for the research under consideration. Second, methods for collecting empirical data and coding study variables are defined. Third, explaining statistic techniques. This work has also followed these steps. 


\section{Inclusion Criteria}

All papers included in the baseline search were screened and evaluated for consideration for inclusion in the meta-analysis based on the following criteria: (a) written in English; (b) peer-reviewed publication; (c) in Primary, Secondary Education Setting and higher education; (d) using the RME Approach; (d) the experimental study used a control class; (e) it contains sufficient statistical data for determining effect sizes, and (f) full article available.

\section{Data collection}

Studi utama diperoleh dengan menggunakan istilah yang relevan dari database online (see Figure 1). Data filtering using Preferred Reporting Items for Systematic Review and Meta Analysis (PRISMA; see Figure 1) protocol. The PRISMA protocol is a systematic review method that supports high-quality meta-analyzes (Pigott \& Polanin, 2020).

According to the search results, there were 241 studies that examined RME in total. 189 studies passed the screening stage, but 103 did not match the criteria. Following that, 48 studies were removed from the analysis due to the lack of complete statistical data. As a result, 38 distinct studies were included in the analysis. Due to the fact that several studies included more than one group, 54 independent samples were analyzed in this meta-analysis. The specific studies that were analyzed are included in Appendix 1.

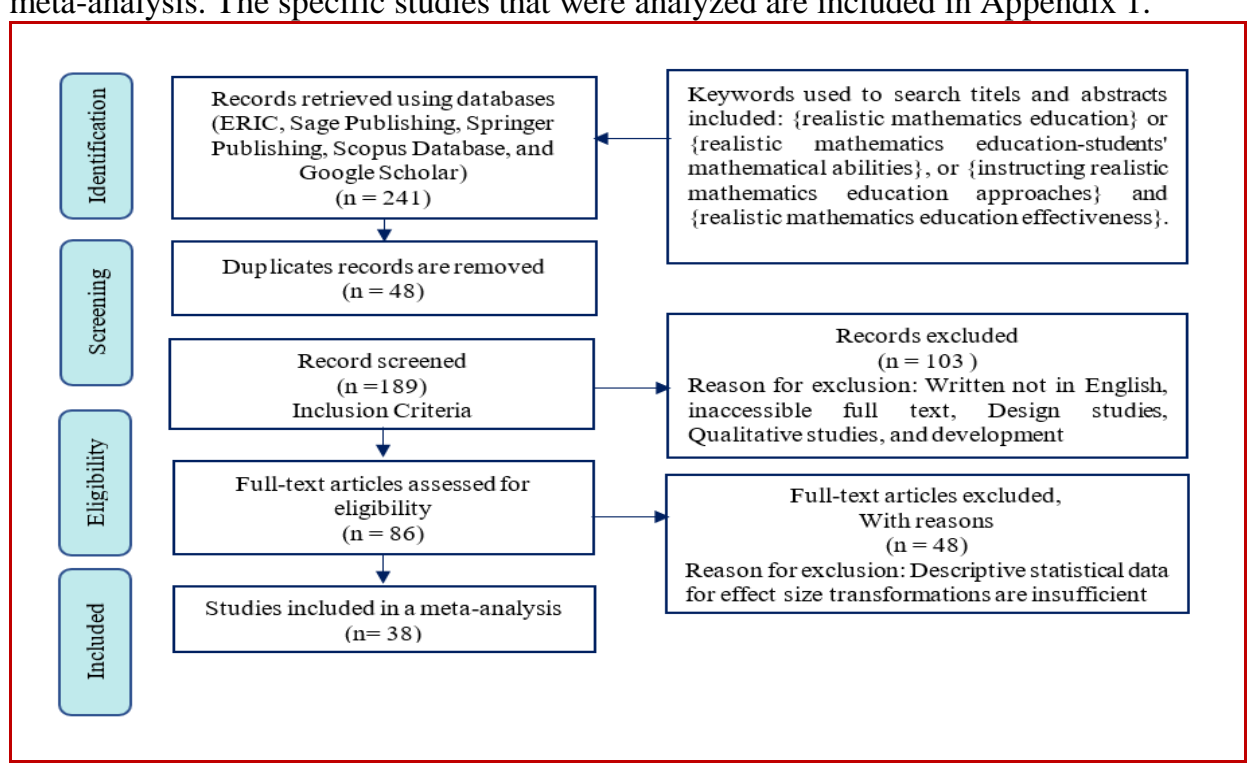

Figure 1

A flow chart illustrating how PRISMA was used to conduct a meta-analysis of an experimental investigation on RME.

\section{Process of Coding and Reliability Test}

The studies that were included in the analysis were further coded according to the research objectives. A research instrument is a coding technique that is used to 
transform the results of particular investigations into numerical data. This information includes sample size, differences in education levels, duration of experimental intervention, learning combinations, and countries of implementation of the RME ". By using this sheet, variable and effect size information were coded separately for each study by two researchers outside the project. Both are doctorate candidates who have completed courses in data analysis and meta-analysis in the past. In order to assess reliability, the Cohen's Cappa $(\kappa(7))$ coefficient is used, this is an impressive statistic that is useful for the purpose of determining the degree of agreement between coders (McHugh, 2012). The calculation of Cohen's kappa is done according to the following formula:

$\kappa(7)=\frac{\operatorname{Pr}(a)-\operatorname{Pr}(e)}{1-\operatorname{Pr}(e)}$

Where $\operatorname{Pr}$ (a) denotes an agreement that was actually seen and $\operatorname{Pr}$ (e) denotes a coincidental agreement. A deal level of 0.85 or greater is predefined to be considered high . An agreement level of 0.98 was obtained for this study. Thus there is a substantial to the almost perfect match between coders.

\section{Moderator Variables}

Meta-analysts always identify a moderating variable, that is, the characteristics of the individual study that are related to the study results (Hall \& Rosenthal, 1991). The moderator in this study is a variable that has an effect on the effect of RME. The results of variable coding provide five identifiable moderators, namely: sample size, educational stage, duration of treatment, a combination of learning, and geographical region. The details of the five moderators are written in Table 1.

Table 1

Information about moderator variables

\begin{tabular}{|c|c|c|}
\hline Category & Group & $\mathrm{N}$ \\
\hline \multirow{2}{*}{ Sample Size } & 30 or less & 23 \\
\hline & 31 or over & 31 \\
\hline \multirow{4}{*}{ Educational stage } & Primary school (PS) & 17 \\
\hline & Junior high school (JHS) & 32 \\
\hline & Senior high school (SHS) & 2 \\
\hline & College & 3 \\
\hline \multirow{3}{*}{ Duration of treatment } & 3-4 meetings & 20 \\
\hline & 5 meetings or more & 23 \\
\hline & Unspecified & 11 \\
\hline \multirow{3}{*}{ Combination of learning } & Only RME & 32 \\
\hline & RME + Math Software & 11 \\
\hline & RME + Another method & 11 \\
\hline \multirow{6}{*}{ geographical region } & Indonesia & 43 \\
\hline & Malaysia & 1 \\
\hline & Thailand & 2 \\
\hline & Turkey & 2 \\
\hline & Greece & 3 \\
\hline & United States of America & 3 \\
\hline
\end{tabular}




\begin{abstract}
Statistic Analysis
Analyzed data in the meta-analysis is the effect size (Glass, 2015). The effect size in this study is an index that quantifies the magnitude of the RME effect. Each analysis was calculated using the CMA software. The Cohen equation allows a fair approximation, but appears to overestimate the population size (Harwell, 2020). Use the Hedges' g equation to correct this overestimation. As a result, the effect size is calculated using Hedges' g equation, while the interpretation is based on Cohen's (1988) classification: less than 0.2 (negligible effect), between 0.2 and 0.5 (small effect), between 0.5 and 0.8 (moderate effect), between 0.8 and 1.3 (large effect), and greater than 1.3 (large effect) (very large effect). The estimation approach use a random-effects model since it does not presuppose that all studies analyzed would yield the same genuine impact estimate (Pigott \& Polanin, 2020).
\end{abstract}

The p-value is checked, and CMA is used to calculate the heterogeneity test results. That all studies are different and therefore homogenous $\left(\mathrm{H}_{0}\right)$ is not accepted if the $\mathrm{p}$ value is less than 0.05 . not possible to calculate the same population parameters (Borenstein et al., 2009; Kul, Çelik, \& Aksu, 2018; Juandi et al., 2021; Suparman, Juandi, \& Tamur, 2021). In other words, the effect sizes between studies or categories is different (Turgut \& Turgut, 2018). The heterogeneity between study groups suggests that differences in moderators affect the studies' effect sizes (Susanti, Juandi, \& Tamur, 2020; Tamur, Jehadus, Nendi, Mandur, \& Murni, 2020; Yunita, Juandi, Tamur, Adem, $\&$ Pereira, 2020). Since the number of studies included in the analysis was relatively large, we adopted 5\% ( $\mathrm{p}<0.05)$ as the level of significance.

A publication bias check was conducted to prevent misrepresentation of the findings. To the extent that any of the 38 studies included in the review had sample bias, it would show up in the overall summary of reported effect sizes (Borenstein et al., 2009). As a result of this publishing bias, academics are less inclined to publicize inconsequential discoveries than are statistically significant ones (6 percent) (Cooper, 2017). We are concerned that the results of this study may overstate the true magnitude of this effect (Arik \& Yilmaz, 2020; Ferguson \& Heene, 2012; Park \& Hong, 2016). In order to anticipate this, funnel plots and Rosenthal's FSN statistics were examined to assess the possible amount of bias (Borenstein et al., 2009; Tamur, Juandi, \& Kusumah, 2020); Paloloang, Juandi, Tamur, Paloloang, \& Adem, 2020). This research is said to be biasresistant if it reveals a symmetrical distribution along the vertical line (Borenstein et al., 2009). If the impact size is not symmetrically distributed, Rosenthal's fail-safe N (FSN) statistic is used. If FSN/(5k+10)>1, where $\mathrm{k}$ is the number of studies included in the meta-analysis, this research is immune to publishing bias (Mullen, Muellerleile, \& Bryant, 2001).

\title{
FINDINGS
}

Data screening procedures were followed to ensure the studies used in this meta-analysis met the inclusion criteria. After this screening, 38 individual studies, providing 54 independent samples, were analyzed. Table 2 presents the study's name, year of publication, $\mathrm{N}$ (sample size), Educational stage, and ES (effect size). 
Table 2

Summary of analyzed individual studies

\begin{tabular}{|c|c|c|c|c|c|}
\hline No & Study name & Publication year & $\mathrm{N}$ & Educational stage & ES \\
\hline 1 & Huntley et al., 2000a & 2000 & 593 & Junior high school & 0,46 \\
\hline 2 & Huntley et al., 2000b & 2000 & 592 & Junior high school & 0,44 \\
\hline 3 & Huntley et al., 2000c & 2000 & 593 & Junior high school & 0,36 \\
\hline 4 & Fauzan 2002, a & 2002 & 74 & Primary school & 0,40 \\
\hline 5 & Fauzan 2002, b & 2002 & 70 & Primary school & 1,36 \\
\hline 6 & Fauzan 2002, c & 2002 & 69 & Primary school & 0,32 \\
\hline 7 & Palinussa, 2013a & 2013 & 47 & Junior high school & 0,57 \\
\hline 8 & Palinussa, 2013b & 2013 & 59 & Junior high school & 0,70 \\
\hline 9 & Zaranis et al., 2013a & 2013 & 62 & College & 0,12 \\
\hline 10 & Zaranis et al., 2013b & 2013 & 63 & College & 0,63 \\
\hline 11 & Zaranis et al., 2013c & 2013 & 64 & College & 0,43 \\
\hline 12 & Susanti et al., 2014a & 2014 & 185 & Junior high school & 0,54 \\
\hline 13 & Susanti et al., 2014b & 2014 & 53 & Junior high school & 0,46 \\
\hline 14 & Susanti et al., 2014c & 2014 & 132 & Junior high school & 0,42 \\
\hline 15 & Hirza et al., 2014 & 2014 & 164 & Primary school & 0,85 \\
\hline 16 & Zubainur et al., 2014 & 2014 & 50 & Primary school & 0,84 \\
\hline 17 & Wardono et al., 2016a & 2016 & 57 & Junior high school & 1,16 \\
\hline 18 & Wardono et al., 2016b & 2016 & 55 & Junior high school & 1,78 \\
\hline 19 & Mahendra, 2017 & 2017 & 63 & Junior high school & 1,47 \\
\hline 20 & Habsah, 2017a & 2017 & 59 & Junior high school & 2,07 \\
\hline 21 & Habsah, 2017b & 2017 & 59 & Junior high school & 1,90 \\
\hline 22 & Karaca et al., 2017 & 2017 & 45 & Primary school & 1,21 \\
\hline 23 & Supandi et al., 2017 & 2017 & 72 & Junior high school & 0,68 \\
\hline 24 & Zakaria et al., 2017 & 2017 & 61 & Senior high school & 0,96 \\
\hline 25 & Sumirattana et al., 2017a & 2017 & 104 & Junior high school & 1,01 \\
\hline 26 & Sumirattana et al., $2017 \mathrm{~b}$ & 2017 & 104 & Junior high school & 2,02 \\
\hline 27 & Yuanita, 2018a & 2018 & 426 & Junior high school & $-0,36$ \\
\hline 28 & Yuanita, 2018b & 2018 & 426 & Junior high school & 1,00 \\
\hline 29 & Laurens et al, 2018 & 2018 & 50 & Junior high school & 2,72 \\
\hline 30 & Altiparmak et al., 2018 & 2018 & 82 & Primary school & 1,17 \\
\hline 31 & Septriyana et al., 2018 & 2018 & 40 & Primary school & 1,79 \\
\hline 32 & Sofiyah et al., 2018 & 2018 & 66 & Primary school & 2,61 \\
\hline 33 & Ramdhani et al., 2018 & 2018 & 60 & Junior high school & 1,37 \\
\hline 34 & Laurens, 2018 & 2018 & 46 & Primary school & 0,71 \\
\hline 35 & Warsito et al., 2018 & 2018 & 72 & Junior high school & 1,41 \\
\hline 36 & Suryani., 2018 & 2018 & 42 & Junior high school & 0,49 \\
\hline 34 & Laurens, 2018 & 2018 & 46 & Primary school & 0,71 \\
\hline 37 & Kusumaningsih., 2018 & 2018 & 66 & Junior high school & 2,81 \\
\hline 38 & Febriyanti., 2019 & 2019 & 50 & Primary school & 1,80 \\
\hline 39 & Hasbi et al., 2019 & 2019 & 64 & Junior high school & 1,92 \\
\hline 40 & Ndiung, 2019a & 2019 & 102 & Primary school & 0,82 \\
\hline 41 & Ndiung, 2019b & 2019 & 100 & Primary school & 0,03 \\
\hline 42 & Pertiwi, 2019 & 2019 & 69 & Junior high school & 1,09 \\
\hline
\end{tabular}

International Journal of Instruction, January $2022 \bullet$ Vol.15, No.1 
Table 2

Continued

\begin{tabular}{llllll}
\hline No & Study name & Publication year & N & Educational stage & ES \\
\hline 43 & Amrina, 2019 & 2019 & 41 & Senior high school & 0,94 \\
\hline 44 & Junaedi, 2019 & 2019 & 78 & Junior high school & 0,40 \\
\hline 45 & Umbara, 2019 & 2019 & 65 & Junior high school & 0,82 \\
\hline 46 & Ndiung et al., 2019a & 2019 & 101 & Primary school & 0,04 \\
\hline 47 & Ndiung et al., 2019b & 2019 & 101 & Primary school & 0,86 \\
\hline 48 & Marpaung et al., 2020 & 2020 & 66 & Junior high school & 0,62 \\
\hline 49 & Dwi et al., 2020 & 2020 & 58 & Primary school & 0,66 \\
\hline 50 & Son et al., 2020 & 2020 & 95 & Junior high school & 1,41 \\
\hline 51 & Yerizon, 2020 & 2020 & 64 & Junior high school & 1,92 \\
\hline 52 & Kurino, 2020 & 2020 & 40 & Primary school & 1,32 \\
\hline 53 & Yuniati, 2020a & 2020 & 61 & Junior high school & 0,14 \\
\hline 54 & Yuniati, 2020b & 2020 & 60 & Junior high school & 1,43 \\
\hline
\end{tabular}

Note: To represent studies that produce more than one effect size, we use a, b, c. The effect size refers to the Hedges equation, g.

When Table 2 was investigated, only $11.11 \%$ of individual studies were conducted before 2010, and $88.89 \%$ of individual studies were conducted between 2010 and 2020 . In education, junior high school participant occupy the largest proportion (59\%), 31\% are students. PS, $4 \%$ are SHS students, and 6\% are students. Furthermore, based on the main study countries conducted, Indonesia gave the largest contribution (78\%), and the rest were scattered in Malaysia, Thailand, Turkey, Greece, and the United States. Individual studies with more than 30 students are 57\%, and less than 31 students are $43 \%$. Based on treatment duration, $37 \%$ of individual studies were conducted over $3-4$ meetings, $42 \%$ of individual studies were conducted in a range of 5 or more meetings, and the rest were not determined. Finally, by considering the combination of learning, the study that only applies RME is $59 \%$, followed by RME and mathematics software $(21 \%)$, and the rest is RME with other methods.

\section{Results of the Overall Analysis to Address the First Question}

First, this study examined the overall impact of RME on the mathematical abilities of students. Figure 2 presents the research forest plots that illustrate the effect sizes, confidence intervals, and standard errors of the 54 studies. 


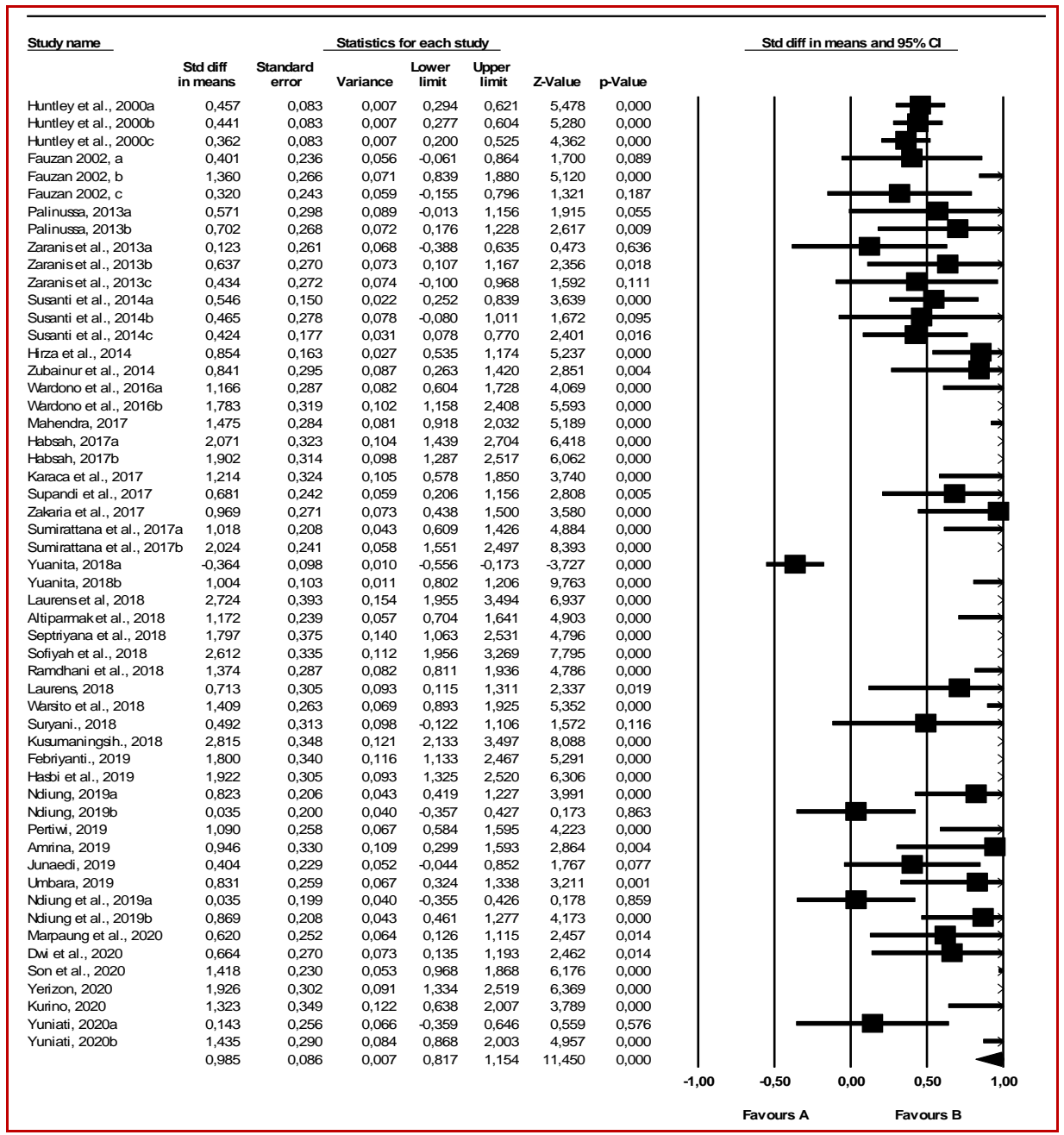

Figure 2

Plot forest research

When Figure 2 is examined, it appears that there are wide levels of confidence and inconsistent response rates, suggesting clear heterogeneity in this study. Figure 2 also presents the random-effect model estimation analysis from 54 studies, and graphically illustrates the effect size (square point). The confidence interval estimates are a horizontal line extending from both sides. It appears that only one effect size is negative, while the other is positive. Furthermore, it is clear that the majority of effect sizes have narrow confidence intervals $(57 \%)$, while $43 \%$ of effect sizes have slightly wide confidence intervals. Table 3 shows the overall effect sizes and the confidence intervals of these studies according to the meta-analysis method. 
Tabel 3

Definition of meta-analysis outcomes by estimation model

\begin{tabular}{|c|c|c|c|c|c|c|c|c|}
\hline \multirow[t]{2}{*}{ Model } & \multirow[t]{2}{*}{$\mathrm{N}$} & \multirow[t]{2}{*}{ Hedges's g } & \multirow{2}{*}{$\begin{array}{l}\text { Standard } \\
\text { error }\end{array}$} & \multicolumn{2}{|c|}{ 95\% Confidence Interval } & \multirow[t]{2}{*}{$\mathrm{Q}$} & \multirow[t]{2}{*}{$\mathrm{P}$} & \multirow[t]{2}{*}{ Decision } \\
\hline & & & & Lower & Upper & & & \\
\hline Fixed-effects & 54 & 0.67 & 0.02 & 0.62 & 0.72 & 487.19 & 0.00 & Reject \\
\hline Random-effects & 54 & 0.97 & 0.08 & 0.80 & 1.14 & & & $\mathrm{H}_{0}$ \\
\hline
\end{tabular}

Table 3 shows that effect size distribution is diverse. As a result, this study's metaanalysis procedure follows the random effect model exactly. Furthermore, to test whether there is publication bias or not, a funnel diagram can be taken into account. Figure 3 presents the funnel plot obtained in the study.

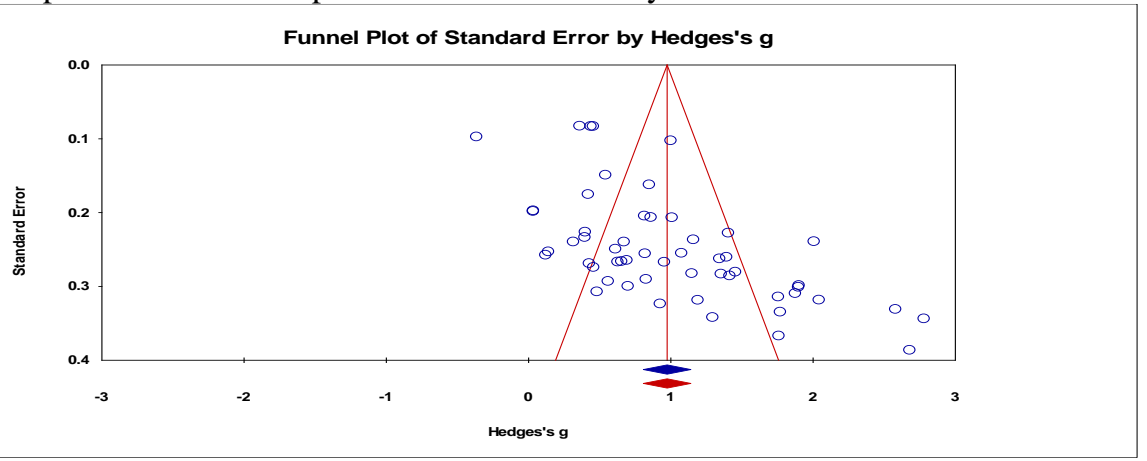

Figure 3

Research funnel plot

As you can see in Figure 3, the distribution of effect sizes is not perfectly symmetrical. It was decided to analyze any publication bias using statistics from Rosenthal's fail-safe $\mathrm{N}$ (FSN). Table 4 summarizes the $\mathrm{N}$ test calculation findings.

Table 4

FSN statistical calculation results

\begin{tabular}{ll}
\hline Bias Condition & \\
\hline The z value for observed studies & 28.61 \\
\hline The P-value for observed studies & 0.00 \\
\hline Alpha & 0.05 \\
\hline Tails & 2 \\
\hline The z value for Alpha & 1.96 \\
\hline Number of Observed Studies & 54 \\
\hline FSN & 1459 \\
\hline
\end{tabular}

From data analysis results, using CMA software, the Rosenthal safe N value is 1459 . Based on the formula Mullen et al. (2001) then $1459 /(5 * 54+10)$, the calculation result is 4.56. It was discovered that this number was higher than 1. According to this estimation, the research examined were not skewed by the publishing of their findings.

\section{Second-Question Analysis: Results of Moderator Variables Analysis}

In light of the mixed findings in the meta-analysis, it is necessary to analyze the Moderator Variable, which is thought to have an impact on how dependent and 
independent variables relate to one another (Arik \& Yilmaz, 2020). The 54 effect sizes derived from 38 separate studies were analyzed in relation to moderator variables such as sample size, differences in educational attainment, duration of experimental intervention, learning combination, and geographical region of RME implementation. Table 5 summarizes the findings of the study.

Table 5

Summary of the results of moderator variable analysis

\begin{tabular}{|c|c|c|c|c|c|c|c|}
\hline \multirow{2}{*}{ Category } & \multirow{2}{*}{ Group } & \multirow{2}{*}{$\mathrm{N}$} & \multirow{2}{*}{ Hedge's g- } & \multicolumn{2}{|c|}{ Heterogeneity } & & \multirow[t]{2}{*}{ Decision } \\
\hline & & & & $\left(\mathrm{Q}_{\mathrm{b}}\right)$ & $\mathrm{df}(\mathrm{Q})$ & & \\
\hline \multirow{2}{*}{ Sample Size } & 30 or less & 23 & 1.19 & \multirow{2}{*}{84.51} & \multirow[b]{2}{*}{1} & \multirow[b]{2}{*}{0.00} & \multirow{2}{*}{ Reject $\mathrm{H}_{0}$} \\
\hline & 31 or over & 31 & 0.56 & & & & \\
\hline \multirow{4}{*}{$\begin{array}{l}\text { Educational } \\
\text { stage }\end{array}$} & Primary school (PS) & 17 & 0.80 & \multirow{4}{*}{10.79} & \multirow{4}{*}{3} & \multirow{4}{*}{0.01} & \multirow{4}{*}{ Reject $\mathrm{H}_{0}$} \\
\hline & Junior high school (JHS) & 32 & 0.85 & & & & \\
\hline & Senior high school (SHS) & 2 & 0.94 & & & & \\
\hline & College & 3 & 0.38 & & & & \\
\hline \multirow{3}{*}{$\begin{array}{l}\text { Duration of } \\
\text { treatment }\end{array}$} & 3-4 meetings & 20 & 0.74 & \multirow{3}{*}{40.52} & \multirow{3}{*}{2} & \multirow{3}{*}{0.00} & \multirow{3}{*}{ Reject $\mathrm{H}_{0}$} \\
\hline & 5 meetings or more & 23 & 0.50 & & & & \\
\hline & Unspecified & 11 & 1.01 & & & & \\
\hline \multirow{3}{*}{$\begin{array}{l}\text { Combination } \\
\text { of learning }\end{array}$} & Only RME & 32 & 0.75 & \multirow{3}{*}{8.54} & \multirow{3}{*}{2} & \multirow{3}{*}{0.01} & \multirow{3}{*}{ Reject $\mathrm{H}_{0}$} \\
\hline & RME + Math Software & 11 & 0.96 & & & & \\
\hline & RME + Another method & 11 & 0.58 & & & & \\
\hline \multirow{6}{*}{$\begin{array}{l}\text { Geographical } \\
\text { region }\end{array}$} & Indonesia & 43 & 1.07 & \multirow{6}{*}{70.06} & \multirow{6}{*}{5} & \multirow{6}{*}{0.00} & \multirow{6}{*}{ Reject $\mathrm{H}_{0}$} \\
\hline & Malaysia & 1 & 0.98 & & & & \\
\hline & Thailand & 2 & 1.437 & & & & \\
\hline & Turkey & 2 & 1.172 & & & & \\
\hline & Greece & 3 & 0.40 & & & & \\
\hline & United States of America & 3 & 0.42 & & & & \\
\hline
\end{tabular}

Table 5 displays the moderator's findings, including the five categories that were examined. First, the size of the sample provides two groups, namely 30 or less and 31 or over. As a result of the heterogeneity test, there was a significant difference between the two groups $(\mathrm{P}<0.05)$. Second, the educational stage category provided three groups, and the effect sizes of the three differed significantly $(\mathrm{P}<0.05)$. Third, the treatment category's duration provides $\mathrm{t}$ categories, and all three are significantly different $(\mathrm{P}$ $<0.05)$. Fourth, the combination of learning gave three groups, and they were significantly different $(\mathrm{P}<0.05)$. Finally, based on the geographical area category, the country where the research was conducted gave different results for the six categories $(\mathrm{P}$ $<0.05)$. This means that the five categories moderate the effect of RME on mathematical abilities.

\section{DISCUSSION}

A search of individual studies on RME was conducted using databases that include ERIC, Sage Publishing, Springer Publishing, Scopus, and Google Scholar. Study selection followed the PRISMA protocol. This stage identified 241 individual studies on RME, and only 38 studies were eligible for analysis. Design, qualitative, and 
development research predominate in individual RME investigations. For the past two decades, design research has dominated research on RME in Indonesia, as described by Prahmana et al. (2020).

The resulting analysis (see Table 3) found that this study's overall effect size is measured at 0.97 based on the random-effect model, which suggests that RME implementation has a major positive effect on the mathematical abilities of students. This is achievable because to RME's ability to enable students to collaborate, discuss, think, and find solutions to real-world problems. Results suggest that students in the experimental group who were rated 15th were roughly equivalent to those in the control group who were ranked sixth. These findings are in line with those of Tamur, Juandi, and Adem (2020), who examined 72 studies on the impact of RME on Indonesian students' mathematical abilities and reported an overall effect size of 1.10 . This finding is not much different from previous meta-analyses that a game-based learning model is effective on mathematics learning achievement (Chen, Shih, \& Law, 2020; Clark, Tanner-Smith, \& Killingsworth, 2016; Wouters \& Van Oostendorp, 2013). Although the number and search for this analysis differed from those of previous studies, this study showed quite similar results, a fact that indicates the superiority of RME.

It becomes out that the five moderator factors have an impact on the study's overall effect size. The summary of results illustrated in Table 5 shows a strong association between RME effectiveness and sample size. The combined effect size for the small sample group (30 or less) differs significantly from the combined effect size for the large sample group (31 or more). A small study group's effect on a small sample is stronger than that of a large sample, according to Tamur, Juandi, and Adem (2020) and Tamur and Juandi (2020). These results prompt educational practitioners to consider sample size in further RME implementation.

Although the previous meta-analysis showed homogeneity of the overall effect sizes between the study groups carried out at PS, JHS, and SHS (e.g., Tamur, Juandi, \& Adem, 2020; and Tamur \& Juandi, 2020), this study revealed different results. Descriptively this study reports a combined effect size that is almost the same as that of studies conducted in primary and secondary schools but differs significantly from studies conducted at universities. Chen, Shih, \& Law (2020) found the same result that the average effect size of the studies that have been conducted in universities (ES = $0.14)$ was smaller than the studies conducted in primary $(E S=0.67)$ and secondary (0.43). These findings provide a tentative assumption that RME is not recommended to be implemented at the university level. This is possible because in the RME framework, students are offered problem situations that they can imagine (Van den HeuvelPanhuizen \& Drijvers, 2014). Meanwhile, students studying at universities may no longer need this framework. In order to verify this allegation, further research is needed.

There was a significant difference in effect size between groups that received therapy for three to four meetings and groups that received treatment for four or more sessions, as shown in Table 5. In the meantime, the effect magnitude was greater in the group whose treatment duration was not specified. The application of RME is most effective if the duration of the treatment is limited to four sessions. In studies in which the treatment 
was continued for more than four meetings, the effect was reduced. These findings support the results of the research of Tamur, Juandi, \& Adem (2020), which reported that the application of RME would get more done with less effort if the duration of treatment was not prolonged too much. The Hawthorne effect's higher effect size associated with shorter treatment duration can be explained (Bayraktar, 2001; Juandi, Kusumah, Tamur, Perbowo, \& Wijaya, 2021; Tamur, Kusumah, et al., 2021). Hawthorne, or novelty, is an effect that occurs when students are stimulated to try harder simply because of the novelty of treatment. However, if the treatment is given for a long time, then its appeal will be lost. This finding is tentative because 11 individual studies did not inform the duration of treatment.

The purpose of this study is to examine the effect of a combination of learning on the implementation of RME. The analytical results indicate that when RME is used in conjunction with mathematical software, it is advantageous. This study is consistent with the findings of a meta-analysis on the use of mathematics software in Indonesia, which concluded that the overall effect size is 1.162 (Tamur, Juandi, \& Kusumah, 2020; Tamur, Fedi, et al., 2021; Tamur, Kusumah, et al., 2021). In this context, the employment of RME in conjunction with mathematical software helps to clarify the complexity of realistic modeling, and its application can allow in-depth problem study, even at an early stage (Bray \& Tangney, 2016; Budinski \& Milinkovic, 2017; Dewolf, Van Dooren, \& Verschaffel, 2017; Kim et al., 2020).

Mathematical learning supported by the RME approach has been applied worldwide. This study also analyzes the application of RME in various countries. It appears that RME has achieved a high level of effectiveness when implemented in Indonesia, Malaysia, Turkey, and Thailand. Meanwhile, the RME applied in Greece and the United States has little effect. This discrepancy in results could be explained by cultural or other factors that have not been identified. Another surprising point relates to the fact that the Netherlands was the first to develop RME but did not report any experimental studies on RME. In the Netherlands, the implementation of RME appears to be more oriented around design research. This is reflected in the statement by Van den Heuvel-Panhuizen \& Drijvers (2020) that teachers must take a proactive part in building RME learning scenarios and designs.

\section{CONCLUSION}

Investigations have been undertaken to integrate findings from the impact of implementing RME over the past two decades. Several of the study's conclusions are that implementing RME has a significant positive effect on students' mathematical abilities when compared to traditional learning. RME is most effective when sample sizes are less than or equal to 30, treatment sessions are 3-4, and mathematical software is used. The application of RME is recommended in elementary schools, junior high schools, high schools, and not recommended in universities. RME is suitable to be implemented in Indonesia, Malaysia, Turkey, and Thailand compared to the United States and Greece. 
The results of this analysis are only based on studies that meet the eligibility criteria. However, there have been found many related studies that cannot be analyzed due to limited statistical data. This study has not identified mathematical ability as a mediating variable. Besides, a study search strategy that relies solely on online has limited this study to analyzing only 38 studies from six countries. A manual search by visiting the library is necessary to reach unpublished publications such as theses and dissertations. Collaborative study amongst countries on the influence of RME is required in the future to produce more complete results.

\section{ACKNOWLEDGMENTS}

I'd like to express my gratitude to James J Lindsay, M Borenstein, and the CMA team at Biostat Englewood in the United States of America for their technical assistance and contributions to the research endeavor. We would like to express our gratitude to the two postgraduate students from the University of Education of Indonesia who served as coders for this research.

\section{REFERENCES}

Ardiyani, S. M. (2018). Realistic Mathematics Education in Cooperative. Journal on Mathematics Education, 9(2), 301-310. Retrieved from https://files.eric.ed.gov/fulltext/EJ1194281.pdf

Arik, S., \& Yilmaz, M. (2020). The effect of constructivist learning approach and active learning on environmental education: A meta-analysis study. International Electronic Journal of Environmental Education, 10(1), 44-84. Retrieved from https://files.eric.ed.gov/fulltext/EJ1239355.pdf

Bayraktar, S. (2001). A Meta-analysis of the Effectiveness of Computer- Assisted Instruction in Science Education. Journal of Research on Technology in Education, 34(2), 173-188. https://doi.org/10.1080/15391523.2001.10782344

Borenstein, M., Hedges, L. V, Higgins, J. P. T., \& Rothstein, H. R. (2009). Introduction to Meta-Analysis. A John Wiley and Sons, Ltd., Publication. https://doi.org/10.1002/9780470743386

Bray, A., \& Tangney, B. (2016). Enhancing student engagement through the affordances of mobile technology: a 21st century learning perspective on Realistic Mathematics Education. Mathematics Education Research Journal, 28(1), 173-197. https://doi.org/10.1007/s13394-015-0158-7

Budinski, N., \& Milinkovic, D. (2017). Transition from Realistic to Real World Problems with the Use of Technology in Elementary Mathematical Education. Acta Didactica Napocensia, 10(1), 53-62. https://doi.org/10.24193/adn.10.1.5

Chen, C. H., Shih, C. C., \& Law, V. (2020). The effects of competition in digital gamebased learning (DGBL): a meta-analysis. Educational Technology Research and Development, 68(4), 1855-1873. https://doi.org/10.1007/s11423-020-09794-1

Çiftçi, Ş. K., \& Yıldız, P. (2019). The Effect of Self-Confidence on Mathematics Achievement: The Meta- Analysis of Trends in International Mathematics and Science 
Study. International Journal of Instruction, 12(2), 683-694. https://doi.org/10.29333/iji.2019.12243a

Clark, D. B., Tanner-Smith, E. E., \& Killingsworth, S. S. (2016). Digital Games, Design, and Learning: A Systematic Review and Meta-Analysis. Review of Educational Research, 86(1), 79-122. https://doi.org/10.3102/0034654315582065

Cooper, H. M. (2017). Research Synthesis and Meta-Analysis: A Step-by-Step Approach (Fifth). Los Angeles: SAGE Publications.

Demirel, M., \& Dağyar, M. (2016). Effects of Problem-Based Learning on Attitude: A Meta-analysis Stud. EURASIA Journal of Mathematics, Science \& Technology Education, 12(8), 2115-2137. https://doi.org/10.12973/eurasia.2016.1293a

Dewolf, T., Van Dooren, W., \& Verschaffel, L. (2017). Can visual aids in representational illustrations help pupils to solve mathematical word problems more realistically? European Journal of Psychology of Education, 32(3), 335-351. https://doi.org/10.1007/s10212-016-0308-7

Fadhli, M., Brick, B., Setyosari, P., Ulfa, S., \& Kuswandi, D. (2020). A Meta-Analysis of Selected Studies on the Effectiveness of Gamification Method for Children. International Journal of Instruction, 13(1), 845-854. https://doi.org/10.29333/iji.2020.13154a

Ferguson, C. J., \& Heene, M. (2012). A Vast Graveyard of Undead Theories: Publication Bias and Psychological Science's Aversion to the Null. Perspectives on Psychological Science, 7(6), 555-561. https://doi.org/10.1177/1745691612459059

Franzen, M. (2020). Meta-analysis. In H. V. Zeigler \& T. . Shackelford (Eds.), Encyclopedia of Personality and Individual Differences (p. 5925). Springer, Cham. https://doi.org/10.1007/978-3-319-24612-3_1326

Glass, G. V. (2015). Meta-analysis at middle age: A personal history. Research Synthesis Methods, 6(3), 221-231. https://doi.org/10.1002/jrsm.1133

Güler, H. K. (2018). Activities Written by Prospective Primary Teachers on Realistic Mathematics Education. International Journal of Evaluation and Research in Education (IJERE), 7(3), 229. https://doi.org/10.11591/ijere.v7i3.14267

Hall, J. A., \& Rosenthal, R. (1991). Testing for moderator variables in meta-analysis: Issues and methods. Communication Monographs, 58(4), 437-448. https://doi.org/10.1080/03637759109376240

Harwell, M. (2020). Growth in the Amount of Literature Reviewed in a Meta-Analysis and Reviewer Resources. Mid-Western Educational Researcher, 32(1), 31-47.

Hasibuan, A. M., Saragih, S., \& Amry, Z. (2019). Development of Learning Materials Based on Realistic Mathematics Education to Improve Problem Solving Ability and Student Learning Independence. International Electronic Journal of Mathematics Education, 14(1), 243-252. https://doi.org/10.29333/iejme/4000

Higgins, S., \& Katsipataki, M. (2015). Evidence from meta-analysis about parental 
involvement in education which supports their children's learning. Journal of Children's Services, 10(3), 280-290. https://doi.org/10.1108/JCS-02-2015-0009

Hirza, B., \& Kusumah, Y. S. (2014). Improving Intuition Skills With Realistic. IndoMS$J M E, 5,27-34$.

Jablonka, E. (2020). Critical Thinking in Mathematics Education. In S Lerman (Ed.), Encyclopedia of Mathematics Education (pp. 713-717). Springer, Cham. https://doi.org/10.1007/978-3-030-15789-0_35

Juandi, D., Kusumah, Y. S., Tamur, M., Perbowo, K. S., Siagian, M. D., Sulastri, R., \& Negara, H. R. P. (2021). The Effectiveness of Dynamic Geometry Software Applications in Learning Mathematics: A Meta- Analysis Study. International Journal $\begin{array}{llll}\text { Interactive } \quad \text { Mobile } \quad \text { Technologies, } & \text { 15(02), }\end{array}$ https://doi.org/10.3991/ijim.v15i02.18853

Juandi, D., Kusumah, Y. S., Tamur, M., Perbowo, K. S., \& Wijaya, T. T. (2021). A meta-analysis of Geogebra software decade of assisted mathematics learning: what to learn and where to go? Heliyon, 7(5), e06953. https://doi.org/10.1016/j.heliyon.2021.e06953

Juandi, D., \& Tamur, M. (2021). The impact of problem-based learning toward enhancing mathematical thinking: A meta-analysis study. Journal of Engineering Science and Technology, 16(4), 3548-3561.

Karsenty, R. (2014). Mathematical Ability. In Stephen Lerman (Ed.), Encyclopedia of Mathematics Education (p. 663). Dordrecht: Springer, Dordrecht. https://doi.org/10.1142/9789814733908

Kim, N. J., Belland, B. R., Lefler, M., Andreasen, L., Walker, A., \& Axelrod, D. (2020). Computer-Based Scaffolding Targeting Individual Versus Groups in Problem-Centered Instruction for STEM Education: Meta-analysis. Educational Psychology Review, 32(2), 415-461. https://doi.org/10.1007/s10648-019-09502-3

Laurens, T., Batlolona, F. A., Batlolona, J. R., \& Leasa, M. (2018). How Does Realistic Mathematics Education ( RME ) Improve Students ' Mathematics Cognitive Achievement? EURASIA Journal of Mathematics, Science and Technology Education, 14(2), 569-578. https://doi.org/10.12973/ejmste/76959

Marzuki, Wahyudin, Cahya, E., \& Juandi, D. (2021). Students' critical thinking skills in solving mathematical problems; a systematic procedure of grounded theory study. International Journal of Instruction, 14(4), 529-548. https://doi.org/10.29333/iji.2021.14431a

McHugh, M. L. (2012). Lessons in biostatistics interrater reliability : the kappa statistic. Biochemica Medica, 22(3), 276-282. https://doi.org/10.11613/BM.2012.031

Mullen, B., Muellerleile, P., \& Bryant, B. (2001). Cumulative meta-analysis: A consideration of indicators of sufficiency and stability. Personality and Social Psychology Bulletin, 27(11), 1450-1462. https://doi.org/10.1177/01461672012711006 
Nurjanah, Latif, B., Yuliardi, R., \& Tamur, M. (2020). Computer-assisted learning using the Cabri 3D for improving spatial ability and self- regulated learning. Heliyon, 6(11), e05536. https://doi.org/10.1016/j.heliyon.2020.e05536

Özdemir, B. G. (2017). Mathematical Practices in a Learning Environment Designed By Realistic Mathematics Education: Teaching Experiment About Cone and Pyramid. European Journal of Education Studies, 3(5), 405-431. https://doi.org/10.5281/zenodo.546599

Palinussa, A. L. (2013). Students' critical mathematical thinking skills and character: IndoMS.J.M.E, 4(1), 75-94.

Paloloang, M. F. B., Juandi, D., Tamur, M., Paloloang, B., \& Adem, A. M. G. (2020). Meta Analisis: Pengaruh Problem-Based Learning Terhadap Kemampuan Literasi Matematis Siswa Di Indonesia Tujuh Tahun Terakhir. AKSIOMA: Jurnal Program Studi Pendidikan Matematika, 9(4), 851-864. https://doi.org/10.24127/ajpm.v9i4.3049

Park, S., \& Hong, S. (2016). The empirical review of meta-analysis published in Korea. Asia Pacific Education Review, 17(2), 313-324. https://doi.org/10.1007/s12564-0169433-X

Pigott, T. D., \& Polanin, J. R. (2020). Methodological Guidance Paper: High-Quality Meta-Analysis in a Systematic Review. Review of Educational Research, 90(1), 24-46. https://doi.org/10.3102/0034654319877153

Prahmana, R. C. I., Sagita, L., Hidayat, W., \& Utami, N. W. (2020). Two Decades of Realistic Mathematics Education Research in Indonesia: A Survey. Infinity Journal, 9(2), 325-340. https://doi.org/10.1007/978-3-030-20223-1_18

Saleh, M., Prahmana, R. C. I., Isa, M., \& Murni. (2018). Improving the reasoning ability of elementary school student through the Indonesian realistic mathematics education. Journal on Mathematics Education, 9(1), 41-53. https://doi.org/10.22342/jme.9.1.5049.41-54

Sawatzki, C. (2015). Context counts: The potential of realistic problems to expose and extend social and mathematical understandings. Mathematics Education in the Margins(Proceedings of the 38th Annual Conference of the Mathematics Education Research Group of Australasia, 555-565. Sunshine Coast: MERGA. Retrieved from https://files.eric.ed.gov/fulltext/ED572526.pdf

Siddaway, A. P., Wood, A. M., \& Hedges, L. V. (2019). How to Do a Systematic Review: A Best Practice Guide for Conducting and Reporting Narrative Reviews, MetaAnalyses, and Meta-Syntheses. Annual Review of Psychology, 70(1), 747-770. https://doi.org/10.1146/annurev-psych-010418-102803

Son, A. L., Darhim, D., \& Fatimah, S. (2020). Students' Mathematical Problem-Solving Ability Based on Teaching Models Intervention and Cognitive Style. Journal on Mathematics Education, 11(2), 209-222. https://doi.org/10.22342/jme.11.2.10744.209222

Suparman, Juandi, D., \& Tamur, M. (2021). Review of problem-based learning trends in 
2010-2020 : A meta-analysis study of the effect of problem-based learning in enhancing mathematical problem-solving skills of Indonesian students. Journal of Physics: Conference Series, 1772(1), 012103. https://doi.org/10.1088/1742-6596/1722/1/012103

Susanti, N., Juandi, D., \& Tamur, M. (2020). The Effect of Problem-Based Learning ( PBL ) Model On Mathematical Communication Skills of Junior High School Students A Meta-Analysis Study. JTAM (Jurnal Teori Dan Aplikasi Matematika), 4(2), 145-154. https://doi.org/10.31764/jtam.v4i2.2481

Tamur, M, Fedi, S., Sennen, E., Marzuki, Nurjaman, A., \& Ndiung, S. (2021). A metaanalysis of the last decade STEM implementation: what to learn and where to go. Journal of Physics: Conference Series, 1882(1), 012082. https://doi.org/10.1088/1742$6596 / 1882 / 1 / 012082$

Tamur, M, Jehadus, E., Nendi, F., Mandur, K., \& Murni, V. (2020). Assessing the effectiveness of the contextual teaching and learning model on students ' mathematical understanding ability: a meta-analysis study. Journal of Physics: Conference Series, 1657(1), 012067. https://doi.org/10.1088/1742-6596/1657/1/012067

Tamur, M, Kusumah, Y. S., Juandi, D., Kurnila, V. S., Jehadus, E., \& Samura, A. O. (2021). A Meta-Analysis of the Past Decade of Mathematics Learning Based on the Computer Algebra System (CAS). Journal of Physics: Conference Series, 1882(1), 012060. https://doi.org/10.1088/1742-6596/1882/1/012060

Tamur, Maximus, Jehadus, E., Negara, H. R. P., Siagian, M. D., Marzuki, M., \& Sulastri, R. (2021). Pembelajaran Selama Krisis COVID - 19: Meta - Analisis dari Sudut Hasil Belajar yang Diukur. Jurnal Riset Teknologi Dan Inovasi Pendidikan (JARTIKA), 4(1), 101-108. https://doi.org/10.36765/jartika.v4i1.413

Tamur, Maximus, \& Juandi, D. (2020). Effectiveness of Constructivism Based Learning Models Against Students Mathematical Creative Thinking Abilities in Indonesia: A Meta-Analysis Study. Mathematics, Science, and Computer Science Education International Seminar, MSCEIS 2019, 1-8. Bandung, Indonesia: EAI. https://doi.org/10.4108/eai.12-10-2019.2296507

Tamur, Maximus, Juandi, D., \& Adem, A. M. G. (2020). Realistic Mathematics Education in Indonesia and Recommendations for Future Implementation: A MetaAnalysis Study. Jurnal Teori Dan Aplikasi Matematika, 4(1), 17-27. https://doi.org/10.31764/jtam.v4i1.1786

Tamur, Maximus, Juandi, D., \& Kusumah, Y. S. (2020). The Effectiveness of the Application of Mathematical Software in Indonesia: A Meta-Analysis Study. International Journal of Instruction, 13(4), 867-884. https://doi.org/10.29333/iji.2020.13453a

Tamur, Maximus, Kusumah, Y. S., Juandi, D., Wijaya, T. T., Nurjaman, A., \& Samura, A. O. (2021). Hawthorne effect and mathematical software based learning: A metaanalysis study. Journal of Physics: Conference Series, 1806(1), 012072. https://doi.org/10.1088/1742-6596/1806/1/012072 
Tanujaya, B., Prahmana, R. C. I., \& Mumu, J. (2017). Mathematics instruction, problems, challenges and opportunities: A case study in Manokwari Regency, Indonesia. World Transactions on Engineering and Technology Education, 15(3), 287-291.

Turgut, S., \& Turgut, I. G. (2018). The Effects of Cooperative Learning on Mathematics Achievement in Turkey: A Meta-Analysis Study. International Journal of Instruction, 11(3), 663-680. https://doi.org/10.12973/iji.2018.11345a

Van den Heuvel-Panhuizen, M, \& Drijvers, P. (2014). Realistic Mathematics Education. In S Lerman (Ed.), Encyclopedia of Mathematics Education (pp. 521-525). Springer Netherlands. https://doi.org/10.1007/978-94-007-4978-8

Wouters, P., \& Van Oostendorp, H. (2013). A meta-analytic review of the role of instructional support in game-based learning. Computers and Education, 60(1), 412425. https://doi.org/10.1016/j.compedu.2012.07.018

Yunita, Y., Juandi, D., Tamur, M., Adem, A. M. G., \& Pereira, J. (2020). A metaanalysis of the effects of problem-based learning on students ' creative thinking in mathematics. Beta: Jurnal Tadris Matematika, 13(2), 104-116. https://doi.org/10.20414/betajtm.v13i2.380

Zulkardi, Z., Putri, R. I. I., \& Wijaya, A. (2020). Two Decades of Realistic Mathematics Education in Indonesia. In Marja Van den Heuvel-Panhuizen (Ed.), International reflections on the Netherlands didactics of Mathematics, ICME-13 Monographs (pp. 325-340). Cham: Springer. https://doi.org/10.1007/978-3-030-20223-18

\section{Appendix 1}

List Of The Studies Included

\begin{tabular}{|c|c|}
\hline Study name, and year & Title \\
\hline Huntley et al., 2000 & $\begin{array}{l}\text { Effects of Standards-Based Mathematics Education: A Study of the Core-Plus Mathematics } \\
\text { Project Algebra and Functions Strand }\end{array}$ \\
\hline Fauzan, 2002 & $\begin{array}{l}\text { Applying Realistic Mathematics Education (RME) in Teaching Geometry In Indonesian } \\
\text { Primary Schools }\end{array}$ \\
\hline Palinussa, 2013 & $\begin{array}{l}\text { Students' Critical Mathematical Thinking Skills and Character: Experiments for Junior } \\
\text { High School Students through Realistic Mathematics Education Culture-Based }\end{array}$ \\
\hline Zaranis et al., 2013 & $\begin{array}{l}\text { The Use of ICT and the Realistic Mathematics Education for Understanding Simple } \\
\text { and Advanced Stereometry Shapes Among University Students }\end{array}$ \\
\hline Susanti et al., 2014 & $\begin{array}{l}\text { Computer-Assisted Realistic Mathematics Education for Enhancing Students' Higher- } \\
\text { Order Thinking Skills }\end{array}$ \\
\hline Hirza et al., 2014 & Improving Intuition Skills with Realistic Mathematics Education \\
\hline Zubainur et al., 2014 & $\begin{array}{l}\text { The effect of using Indonesian realistic mathematics education (PMRI) approach on the } \\
\text { mathematics achievement amongst primary school students }\end{array}$ \\
\hline Wardono et al., 2016 & $\begin{array}{l}\text { Mathematics Literacy on Problem Based Learning with Indonesian Realistic Mathematics } \\
\text { Education Approach Assisted E-Learning Edmodo }\end{array}$ \\
\hline Mahendra et al., 2017 & Problem Posing with Realistic Mathematics Education Approach in Geometry Learning \\
\hline Habsah, 2017 & $\begin{array}{l}\text { Developing Teaching Material Based on Realistic Mathematics and Oriented to the } \\
\text { Mathematical Reasoning and Mathematical Communication }\end{array}$ \\
\hline Karaca, 2017 & $\begin{array}{l}\text { The Effects of Realistic Mathematics Education on Students' Math Self Reports in Fifth } \\
\text { Grades Mathematics Course }\end{array}$ \\
\hline Supandi, 2017 & $\begin{array}{l}\text { Analysis Of Mathematical Representation By React Strategy On The Realistic Mathematics } \\
\text { Education }\end{array}$ \\
\hline Zakaria, 2017 & The Effect of Realistic Mathematics Education Approach on Students' Achievement And \\
\hline
\end{tabular}




\begin{tabular}{|c|c|}
\hline & Attitudes Towards Mathematics \\
\hline $\begin{array}{l}\text { Sumirattana et al., } \\
2017\end{array}$ & $\begin{array}{l}\text { Using realistic mathematics education and the DAPIC problem-solving process to enhance } \\
\text { secondary school students' mathematical literacy }\end{array}$ \\
\hline Yuanita et al., 2018 & $\begin{array}{l}\text { The effectiveness of Realistic Mathematics Education approach: The role of mathematical } \\
\text { representation as moderator between mathematical belief and problem solving }\end{array}$ \\
\hline Laurens et al., 2018 & $\begin{array}{l}\text { How Does Realistic Mathematics Education (RME) Improve Students' Mathematics } \\
\text { Cognitive Achievement }\end{array}$ \\
\hline Altiparmak et al., 2018 & $\begin{array}{l}\text { An Experimental Study on the Effectiveness of Computer Aided Realistic Mathematics } \\
\text { Education }\end{array}$ \\
\hline Septriyana et al., 2018 & $\begin{array}{l}\text { The Influence of Realistic Mathematics Education (RME) Approach on Students' } \\
\text { Mathematical Problem Solving Ability }\end{array}$ \\
\hline Sofiyah et al., 2018 & $\begin{array}{l}\text { The Influence of Realistic Mathematics Education (RME) Approach Based on Mandailing } \\
\text { Culture on Student Self-Regulated Learning in Class V of Islamic Elementary School } \\
\text { Sihadabuan Padang sidimpuan }\end{array}$ \\
\hline Ramdhani et al., 2018 & $\begin{array}{l}\text { Comparison of Mathematical Reasoning of SMP Students Between Learning Using A } \\
\text { Realistic Approach with Open Ended Approach }\end{array}$ \\
\hline Laurens, 2018 & $\begin{array}{l}\text { The Effectiveness of Local Wisdom Based-Realistic Mathematics Learning to Improve } \\
\text { Learners' Characters at State Elementary Schools in Ambon City }\end{array}$ \\
\hline Warsito et al., 2018 & $\begin{array}{l}\text { Improving students' mathematical representational ability through RME-based progressive } \\
\text { mathematization }\end{array}$ \\
\hline Suryani et al., 2018 & $\begin{array}{l}\text { Improving the Mathematical Representation and Self Confidence through Realistic } \\
\text { Mathematics Education Approach for Junior High School }\end{array}$ \\
\hline $\begin{array}{l}\text { Kusumaningsih et al., } \\
2018\end{array}$ & $\begin{array}{l}\text { Improvement Algebraic Thinking Ability Using Multiple Representation Strategy on } \\
\text { Realistic Mathematics Education }\end{array}$ \\
\hline Febriyanti et al., 2019 & $\begin{array}{l}\text { The Effect of The Realistic Mathematics Education (RME) Approach and The Initial } \\
\text { Ability of Students on The Ability of Student Mathematical Connection }\end{array}$ \\
\hline Hasbi et al., 2019 & Mathematical Connection Middle-School Students sth $^{\text {in Realistic Mathematics Education }}$ \\
\hline Ndiung, 2019 & $\begin{array}{l}\text { Treffinger Creative Learning Model with RME Principles on Creative Thinking Skill by } \\
\text { Considering Numerical Ability }\end{array}$ \\
\hline Pertiwi, 2019 & $\begin{array}{l}\text { Enhancing mathematical reasoning ability and self confidence students' through realistic } \\
\text { mathematics education approach with geogebra }\end{array}$ \\
\hline Amrina et al, 2019 & Using Realistic Mathematics Education Approach to Learn Linear Program \\
\hline Junaedi et al., 2019 & $\begin{array}{l}\text { Improving Student's Reflective Thinking Skills Through Realistic Mathematics Education } \\
\text { Approach }\end{array}$ \\
\hline Umbara et al., 2019 & $\begin{array}{l}\text { Implementation of Realistic Mathematics Education Based on Adobe Flash Professional } \\
\text { CS6 to Improve Mathematical Literacy }\end{array}$ \\
\hline Ndiung et al., 2019 & $\begin{array}{l}\text { The Treffinger Learning Model with RME Principles on Mathematics Learning Outcome } \\
\text { by Considering Numerical Ability }\end{array}$ \\
\hline Marpaung et al., 2020 & $\begin{array}{l}\text { The Effect of Mathematics Realistic Education Aided by Mathematics Software towards } \\
\text { the Process of Solving Mathematical Communication Problems of Junior High School } \\
\text { Students }\end{array}$ \\
\hline Dwi et al., 2020 & $\begin{array}{l}\text { The Effect of Realistic Mathematics Education (RME) on The Understand Mathematical } \\
\text { Concepts Skills of Elementary Students Using Hypothetical Learning Trajectory (HLT) }\end{array}$ \\
\hline Son et al., 2020 & $\begin{array}{l}\text { Students' Mathematical Problem-Solving Ability Based on Teaching Models Intervention } \\
\text { and Cognitive Style }\end{array}$ \\
\hline Yerizon et al., 2020 & $\begin{array}{l}\text { Improving Student's Mathematical Communication Skills Through Mathematics } \\
\text { Worksheet Based on Realistic Mathematics Education }\end{array}$ \\
\hline Kurino et al., 2020 & $\begin{array}{l}\text { The Effect of Realistic Mathematic Education towards Student' Learning Motivation in } \\
\text { Elementary School }\end{array}$ \\
\hline Yuniati et al., 2020 & $\begin{array}{l}\text { The influence of realistic mathematics education (RME) approach with the TANDUR on } \\
\text { understanding the concepts and solving mathematical problems on grade } 8 \text { in smp negeri } 1 \\
\text { pantai cermin }\end{array}$ \\
\hline
\end{tabular}

International Journal of Instruction, January $2022 \bullet$ Vol.15, No.1 